\title{
PERBEDAAN LATIHAN FISIK DUA DAN EMPAT KALI PER MINGGU TERHADAP PENINGKATAN KEBUGARAN JASMANI MAHASISWA FAKULTAS KEDOKTERAN UNJANI ANGKATAN 2009
}

\author{
Odih Fahruzi, Nuriatin, Andri Andrian Rusman
}

Fakultas Kedokteran Universitas Jenderal Achmad Yani, Cimahi, Jawa Barat

\begin{abstract}
ABSTRAK
Kebugaran jasmani adalah kemampuan tubuh untuk menyesuaikan fungsi alat tubuhnya dalam batas fisiologis terhadap lingkungan dan atau kerja fisik yang cukup efisien tanpa lelah secara berlebihan. Untuk mendapatkan kebugaran jasmani yang maksimal harus dilakukan latihan fisik dengan frekuensi, intensitas, waktu, dan tipe latihan tertentu. Ada beberapa komponen untuk meningkatkan kebugaran jasmani, diantaranya diantaranya kekuatan otot, daya tahan otot, komposisi tubuh, kelenturan tubuh, dan daya tahan kardiorespiratorik. Diteliti daya tahan kardiorespiratorik dengan indikator $\mathrm{Vo}_{2}$ maks. Tujuan dari penelitian ini adalah untuk mengetahui perbedaan latihan fisik dua dan empat kali perminggu selama 7 minggu terhadap peningkatan kebugaran mahasiswa Fakultas Kedokteran Unjani Angkatan 2009. Subyek penelitian penulis adalah Mahasiswa Fakultas Kedokteran Unjani angkatan 2009. Penelitian menggunakan metode metode eksperimental yang di analisis menggunakan uji $T$ Independen. Jumlah sampel sebanyak 14 orang dengan metode purposive sampling, kemudian dibagi menjadi dua kelompok, yaitu 7 orang latihan fisik dua kali per minggu, dan 7 orang latihan fisik empat kali per minggu. Pengukuran $\mathrm{VO}_{2}$ maks dengan menggunakan metode cooper test sebelum dan sesudah latihan fisik (lari) selama 7 minggu, kemudian dianalisis dengan menggunakan SPSS Uji T versi 17. Dari hasil penelitian didapatkan kesimpulan, hasil perbedaan yang signifikan pada latihan dua dan empat kali perminggu selama tujuh minggu terhadap $\mathrm{VO}_{2}$ maks sebelum dan sesudah latihan, dan terdapat perbedaan yang signifika antara latihan dua dan empat kali per minggu selama tujuh minggu terhadap $\mathrm{Vo}_{2}$ maks.
\end{abstract}

Kata kunci: kebugaran jasmani, kardiorespiratorik, $\mathrm{Vo}_{2}$ maks, frekuensi, latihan

\section{PENDAHULUAN}

Setiap manusia pasti ingin memiliki kehidupan yang sehat. Sehat adalah keadaan lengkap fisik, mental, dan juga tidak adanya penyakit atau kelemahan (WHO, 1948). Cara untuk mendapatkan kehidupan yang sehat adalah dengan menjaga kebersihan, mengkonsumsi makanan yang sehat, tidak ada stress psikologis dan berolahraga yang teratur dan seimbang. Dengan berolahraga kita dapat mencapai kebugaran jasmani yang menunjang kesehatan fisik. Kebugaran jasmani adalah kemampuan tubuh untuk menyesuaikan fungsi alat tubuhnya dalam batas fisiologis terhadap lingkungan dan atau kerja fisik yang cukup efisien tanpa lelah secara berlebihan. Kebugaran jasmani mempunyai tingkat yang berlainan bagi setiap orang. Terutama kebugaran jasmani atlet dan non atlet. Kebugaran jasmani pada atlet lebih baik dibandingkan dengan non atlet, hal itu dikarenakan program latihan fisik pada atlet lebih sering dibandingkan dengan non atlet.

Untuk mendapatkan kebugaran jasmani yang maksimal harus dilakukan latihan fisik dengan beban tertentu yaitu frekuensi, intensitas, waktu, dan tipe latihan. Adapun pola latihan fisik yang dapat menunjang dalam meningkatkan kebugaran ada dua macam, yaitu latihan anaerobik dan aerobik. Latihan aerobik sangat penting dalam menunjang kebugaran jasmani.

Pada saat latihan aerobik, kemampuan daya tahan kardiorespiratorik yang dilatih, akan tetapi bukan hanya kemampuan kardiorespiratorik saja yang menunjang kebugaran jasmani, tapi ada beberapa komponen lain, diantaranya kekuatan otot, daya tahan otot, komposisi tubuh dan kelenturan tubuh. Kemampuan sistem kardiorespiratorik dapat diukur dengan indikator, yaitu $\mathrm{Vo}_{2}$ maks. $\mathrm{Vo}_{2}$ maks adalah tingkat konsumsi oksigen dalam metabolisme maksimum. Oleh karena itu peneliti memilih $\mathrm{Vo}_{2}$ maks sebagai indikator untuk menentukan kebugaran jasmani. 
Meskipun sudah ada penelitian tentang pengaruh manfaat latihan terhadap peningkatan kebugaran jasmani, peneliti ingin mengetahui lebih lanjut tentang pengaruh frekuensi latihan terhadap kebugaran jasmani. Sehingga peneliti mengambil judul "Perbedaan Latihan Fisik Dua Dan Empat Kali Per minggu terhadap Peningkatan Kebugaran Jasmani Mahasiswa Fakultas Kedokteran UNJANI Angkatan 2009”.

Penelitian ini bertujuan untuk mengetahui perbedaan latihan fisik dua dan empat kali per minggu terhadap peningkatan kebugaran jasmani pada mahasiswa Fakultas Kedokteran Universitas Jendral Achmad Yani Angkatan 2009.

\section{MATERI DAN METODE}

\section{Definisi Kebugaran Jasmani}

Kebugaran jasmani adalah kemampuan tubuh untuk menyesuaikan fungsi alat tubuhnya dalam batas fisologi terhadap lingkungan (ketinggian, kelembapan suhu, dan sebagainya) dan atau kerja fisik dengan yang cukup efisien tanpa lelah secara berlebihan. Secara umum pengertian kebugaran jasmani adalah kemampuan seseorang untuk menjalankan pekerjaan sehari hari dengan ringan dan mudah tanpa merasakan kelelahan yang berarti dan masih mempunyai cadangan tenaga untuk melakukan kegiatan yang lain

\section{Komponen Kebugaran Jasmani}

Derajat kebugaran jasmani dapat ditentukan dengan menilai komponen-komponen kebugaran jasmani yang meliputi daya tahan kardiorespiratorik, kekuatan otot, daya tahan otot, komposisi tubuh dan kelenturan tubuh.

Daya tahan kardiorespiratorik didefinisikan sebagai kemampuan untuk melakukan latihan pada otot besar, dinamik, dengan intensitas sedang sampai tinggi untuk waktu yang lama. Kinerja latihan semacam itu tergantung pada status fungsional sistem respirasi , kardiovaskular, dan otot skelet. Ketahana kardiorespiratorik dianggap berkaitan dengan kesehatan karena (a) tingkat kebugaran yang rendah telah dikaitkan dengan resiko tinggi kematian dini dari semua sebab dan khususnya dari penyakit kardiovaskular, dan (b) kebugaran yang lebih tinggi dikaitkan dengan lebih tingginya aktivitas fisik yang teratur, yang sebaliknya berkaitan dengan banyak manfaat kesehatan.

Kekuatan otot adalah kemampuan otot untuk mengerahkan kekuatan selama kegiatan. Kunci untuk membuat otot kuat adalah melatih dengan mendapatkan beban, baik yang berasal dari berat atau gravitasi.

Daya tahan otot adalah kemampuan otot untuk terus melakukan kontraksi berulang-ulang selama periode waktu tertentu untuk menyebabkan kelelahan, atau untuk mempertahankan persentasi spesifik MVC secara statistik dalam periode waktu yang lama. Uji lapangan sederhana, seperti uji sit-up 60 detik atau jumlah maksimum push-up yang bisa dilakukan tanpa istirahat, bisa digunakan untuk mengevaluasi ketahanan kelompok otot abdomen dan otot tubuh bagian atas. 
Meskipun tidak secara langsung terkait dengan kinerja olahraga atau kualitas hidup, komposisi tubuh adalah tetap merupakan komponen penting dari kebugaran. Komposisi tubuh mengacu pada jumlah relatif otot, lemak, tulang, dan bagian penting lain dari tubuh.

Kelenturan adalah kemampuan maksimum untuk menggerakan sendi dalam jangkauan gerak. Parameter ini tergantung pada sejumlah variabel spesifik, termasuk distensibilitas kapsul sendi, suhu otot, viskositas otot, dll.

\section{Pengertian $\mathrm{Vo}_{2}$ maks}

$\mathrm{Vo}_{2}$ maks adalah penyerapan oksigen maksimal atau volume maksimum oksigen yang dapat digunakan dalam satu menit selama latihan maksimal atau menyeluruh. $\mathrm{Vo}_{2}$ maks atau penyerapan oksigen maksimal adalah salah satu faktor yang dapat menentukan kapasitas seorang atlet untuk melakukan latihan yang berkelanjutan dan berhubungan dengan ketahanan aerobik. Hal ini umumnya dianggap indikator terbaik untuk daya tahan jantung dan kebugaran aerobik. Seorang atlet profesional biasanya memiliki $\mathrm{Vo}_{2}$ maks yang tinggi. Dan beberapa studi menunjukkan bahwa sebagian besar disebabkan oleh genetika, meskipun pelatihan telah terbukti dapat meningkatkan $\mathrm{Vo}_{2}$ maks sampai dua puluh persen. Tujuan utama program ketahanan paling pelatihan adalah untuk meningkatkan jumlah ini.

$\mathrm{Vo}_{2}$ maks merupakan produk dari jumlah darah yang dipompa oleh jantung (cardiac output) dan jumlah oksigen yang diambil dari darah ketika darah melewati jaringan tubuh, khususnya otototot yang sedang bekerja. Ketika $\mathrm{Vo}_{2}$ maks tercapai, berarti konsumsi oksigen oleh tubuh mencapai tingkat tinggi. Jumlah oksigen yang digunakan,diukur dengan menghitung perbedaan kandungan oksigen antara darah arteri dengan darah vena, yang dikenal sebagai perbedaan arteriovenosa. Untuk mengevaluasi ketahanan kardiorespirasi, nilai $\mathrm{Vo}_{2}$ maks dinyatakan relatif terhadap berat badan (seperti, $\mathrm{ml} / \mathrm{kg} / \mathrm{min}$ ).

Konsumsi oksigen dapat dihitung dengan rumus:

$\mathrm{Vo}_{2}$ maks = curah jantung (cardiac output) $\times$ perbedaan arterio vena

$=$ (heart rate $\mathrm{x}$ stroke volume) $\mathrm{x}$ perbedaan oksigen arteriovena

Nilai normal $\mathrm{Vo}_{2}$ maks dapat digambarkan pada tabel berikut:

Tabel 1. Nilai $\mathrm{Vo}_{2}$ maks pada wanita $(\mathrm{ml} / \mathrm{kg} / \mathrm{mnt})$

\begin{tabular}{ccccccc}
\hline Umur & $\begin{array}{c}\text { Sangat } \\
\text { Buruk }\end{array}$ & Buruk & Cukup & Baik & $\begin{array}{c}\text { Baik } \\
\text { Sekali }\end{array}$ & Superior \\
\cline { 2 - 7 } & & & & & & \\
$\mathbf{1 3 - 1 9}$ & $<25,0$ & $25,0-30,9$ & $31,0-34,9$ & $35,0-38,9$ & $39,0-41,9$ & $>41,9$ \\
$\mathbf{2 0 - 2 9}$ & $<23,6$ & $23,6-28,9$ & $29,0-32,9$ & $33,0-36,9$ & $37,0-41,0$ & $>41,0$ \\
$\mathbf{3 0 - 3 9}$ & $<22,8$ & $22,8-26,9$ & $27,0-31,4$ & $31,5-35,6$ & $35,7-40,0$ & $>40,0$ \\
$\mathbf{4 0 - 4 9}$ & $<21,0$ & $21,0-24,4$ & $24,5-28,9$ & $29,0-32,8$ & $32,9-36,9$ & $>36,9$ \\
$\mathbf{5 0 - 5 9}$ & $<20,2$ & $20,2-22,7$ & $22,8-26,9$ & $27,0-31,4$ & $31,5-35,7$ & $>35,7$ \\
$>\mathbf{6 0}$ & $<17,5$ & $17,5-20,1$ & $20,2-24,4$ & $24,5-30,2$ & $30,3-31,4$ & $>31,4$ \\
\hline
\end{tabular}


Tabel 2. Nilai $\mathrm{Vo}_{2}$ maks pada pria $(\mathrm{ml} / \mathrm{kg} / \mathrm{mnt})$

\begin{tabular}{ccccccc}
\hline Umur & $\begin{array}{c}\text { Sangat } \\
\text { Buruk }\end{array}$ & Buruk & Cukup & Baik & $\begin{array}{c}\text { Baik } \\
\text { Sekali }\end{array}$ & Superior \\
\cline { 2 - 2 } $\mathbf{1 3 - 1 9}$ & $<35,0$ & $35,0-38,3$ & $38,4-45,1$ & $45,2-50,9$ & $51,0-55,9$ & $>55,9$ \\
$\mathbf{2 0 - 2 9}$ & $<33,0$ & $33,0-36,4$ & $36,5-42,4$ & $42,5-46,4$ & $46,5-52,4$ & $>52,4$ \\
$\mathbf{3 0 - 3 9}$ & $<31,5$ & $31,5-35,4$ & $35,5-40,9$ & $41,0-44,9$ & $45,0-49,4$ & $>49,4$ \\
$\mathbf{4 0 - 4 9}$ & $<30,2$ & $30,2-33,5$ & $33,6-38,9$ & $39,0-43,7$ & $43,8-48,0$ & $>48,0$ \\
$\mathbf{5 0 - 5 9}$ & $<26,1$ & $26,1-30,9$ & $31,0-35,7$ & $35,8-40,9$ & $41,0-45,3$ & $>45,3$ \\
$>\mathbf{6 0}$ & $<20,5$ & $20,5-26,0$ & $26,1-32,2$ & $32,3-36,4$ & $36,5-44,2$ & $>44,2$ \\
\hline
\end{tabular}

\section{Rancangan Penelitian}

Penelitian menggunakan metode eksperimental yang di analisis menggunakan uji T Independen, yaitu subyek yang sama diperiksa pra- dan pasca-intervensi.

\section{Subyek Penelitian}

Subyek penelitian adalah Mahasiswa Fakultas Kedokteran Universitas Jenderal Achmad Yani angkatan 2009 yang memenuhi kriteria inklusi yaitu jenis kelamin laki-laki, usia 18-20 tahun, sehat jasmani, bersedia menjadi subyek dalam penelitian dengan menandatangani informed consent. Keriteria ekskusi yaitu cacat anggota gerak bawah dan mengikuti latihan fisik atau olahraga rutin setiap minggu.

\section{Ukuran Sampel}

Pemilihan sampel dilakukan dengan menggunakan metode judgmental sampling atau purposive sampling yang didapatkan sampel sebanyak 14 orang berdasarkan kriteria inklusi dan eksklusi.

\section{Prosedur Penelitian}

Sebelum dilakukan penelitian, peneliti memberikan kuesioner kepada Mahasiswa Fakultas Kedokteran Angkatan 2009. Mahasiswa yang memenuhi kriteria inklusi dan eksklusi, dilakukan pemeriksaan kesehatan dan tingkat kebugaran kemudian menandatangani informed consent. Selanjutnya dilakukan pemeriksaan kebugaran awal dengan menggunakan metode cooper test, setelah itu populasi subyek dibagi menjadi dua kelompok. Kelompok pertama melakukan latihan fisik dua kali per minggu dan kelompok kedua melakukan latihan fisik empat kali per minggu. Kedua kelompok tersebut melakukan latihan fisik selama tujuh minggu masing-masing dengan berlari selama 20 menit. Setelah melakukan latihan fisik selama tujuh minggu, kedua kelompok dilakukan pemeriksaan kebugaran jasmani kembali dengan menggunakan metode cooper test.

Metode pengukuran dengan cooper test yaitu subyek melakukan pemanasan 10-15 menit, lari maksimal dalam 12 menit, mencatan total jarak yang ditempuh dalam 12 menit, jarak yang dicapai dihitung dengan rumus $\mathrm{Vo}_{2}$ maks = (jarak dalam meter yang didapat dalam 12 menit $504.9) \div 44.73$. setelah mendapatkan hasil kemudian dilakukan pencatatan hasil $\mathrm{vo}_{2}$ maks.

\section{Analisis Data}

Data hasil penelitian dari subyek yang diberi perlakuan dua dan empat kali per minggu, menggunaka $U j i T$ Independent dengan menggunakan program SPSS versi 17. 


\section{HASIL DAN PEMBAHASAN}

Tabel 3. Gambaran $\mathrm{Vo}_{2}$ maks rata-rata latihan dua kali per minggu sebelum dan

\begin{tabular}{ccccc}
\multicolumn{4}{c}{ sesudah diberi perlakuan selama tujuh minggu (kelompok A) } \\
\hline \multirow{2}{*}{ No } & \multicolumn{2}{c}{ Rata - rata } & Selisih & $\mathrm{P}$ \\
\cline { 2 - 3 } 1 & Sebelum & Sesudah & & \\
2 & 26,83 & 32,31 & 5,48 & \\
3 & 24,71 & 30,52 & 5,81 & \\
4 & 31,41 & 37,45 & 6,04 & \\
5 & 24,71 & 30,52 & 5,81 & \\
6 & 31,41 & 36,11 & 4,70 & \\
7 & 35,73 & 40,58 & 4,85 & \\
\hline \multicolumn{5}{c}{} \\
\cline { 2 - 4 }
\end{tabular}

Berdasarkan tabel diatas didapatkan hasil analisis statistik dengan tingkat kepercayaan 95\% $(<0,05)$ dipeeroleh nilai $\mathrm{p}=0,000$ menunjukan adanya perbedaan yang signifikan pada latihan dua kali per minggu sebelum dan sesudah latihan fisik selama tujuh minggu terhadap Vo2 maks

Tabel 4. Gambaran $\mathrm{Vo}_{2}$ maks rata-rata latihan empat kali per minggu sebelum dan

\begin{tabular}{ccccc}
\multicolumn{2}{c}{ sesudah diberi perlakuan selama tujuh minggu (kelompok B) } \\
\cline { 1 - 2 } No & \multicolumn{2}{c}{ Rata - rata } & Selisih & $\mathrm{p}$ \\
\cline { 2 - 3 } 1 & Sebelum & Sesudah & & \\
2 & 29,18 & 35,86 & 6,68 & \\
3 & 23,14 & 32,31 & 9,17 & \\
4 & 30,12 & 38,79 & 8,67 & \\
5 & 40,62 & 45,05 & 4,43 & \\
6 & 41,47 & 44,83 & 3,36 & \\
7 & 38,86 & 44,60 & 5,74 & \\
\hline
\end{tabular}

Berdasarkan tabel diatas didapatkan hasil analisis statistik dengan tingkat kepercayaan 95\% $(<0,05)$ dipeeroleh nilai $\mathrm{p}=0,000$ menunjukan adanya perbedaan yang signifikan pada latihan empat kali per minggu sebelum dan sesudah latihan fisik selama tujuh minggu terhadap Vo2 maks. Perbedaan sebelum dan sesudah diberi perlakuan juga dapat di gambarkan pada grafik dibawah ini:

Dari kedua data yang didapat yaitu nilai $\mathrm{Vo}_{2}$ maks sesudah melakukan latihan fisik selama tujuh minggu yang dibagi menjadi dua kelompok dengan latihan dua dan empat kali per minggu, kemudian dilakukan analisis data dengan menggunakan program SPSS versi 17 untuk Uji T Independen. Semua data yang didapat telah terdistribusi dengan normal dengan menggunakan uji normalitas yang terdapat di lampiran 5. Berikut adalah tabel yang menunjukan perbedaan latihan dua dan empat kali per minggu setelah diberi perlakuan:

Tabel 5. Perbedaan latihan dua dan empat kali per minggu terhadap Peningkatan $\mathrm{Vo}_{2}$ maks

\begin{tabular}{cccc}
\hline Kelompok & Rata-rata $\mathrm{Vo}_{2}$ maks akhir & $\begin{array}{c}\text { Rata-rata } \\
\text { Peningkatan } \\
\mathrm{Vo}_{2} \text { maks }\end{array}$ & $\mathrm{P}$ \\
\hline Dua kali per minggu (A) & 35.08 & 5,66 & 0,042 \\
Empat kali per minggu (B) & 40.67 & 6,53 & \\
\hline
\end{tabular}


Berdasarkan tabel diatas didapatkan hasil analisis statistik dengan tingkat kepercayaan 95\% $(<0,05)$ diperoleh nilai $\mathrm{p}=0,042$, artinya "terdapat perbedaan yang signifikan antara latihan dua dan empat kali per minggu selama tujuh minggu terhadap $\mathrm{Vo}_{2}$ maks. Hal ini juga didukung oleh peningkatan rata-rata selisih antara $\mathrm{Vo}_{2}$ maks sebelum dan sesudah perlakuan selama tujuh minggu.

Perbedaan latihan dua dan empat kali perminggu dikarenakan frekuensi latihan sangat berpengaruh terhadap tingkat kebugaran jasmani, sehingga semakin banyak frekuensi latihan dalam satu minggu maka semakin tinggi nilai $\mathrm{Vo}_{2}$ maks.

Setelah melakukan olahraga aerobik secara teratur, tubuh akan merespon secara fisiologis dari olahraga yang dilakukan, seperti luas permukaan yang tersedia untuk pertukaran dapat meningkat secara fisiologis untuk meningkatkan kecepatan pertukaran gas. Pada keadaan istirahat, sebagian kapiler paru biasanya tertutup karena tekanan sirkulasi paru, yang secara normal rendah, tidak mampu membuka semua kapiler yang ada. Selama olahraga, pada saat tekanan darah paru meningkat akibat peningkatan curah jantung, banyak kapiler paru yang sebelumnya tertutup menjadi terbuka. Hal ini meningkatkan luas permukaan darah yang tersedia untuk proses pertukaran. Selain itu, selama olahraga membran alveolus lebih teragang daripada normal karena penignkatan tidal volum (bernafas lebih dalam). Peregangan itu meningkatkan luas permukaan alveolus dan menurunkan ketebalan membran alveolus. Secara kolektif, perubahan-perubahan diatas meningkatkan pertukaran gas selama olahraga.

Olahraga daya tahan (aerobik) yang teratur juga dapat menginduksi perubahan metabiolik di dalam serat-serat oksidatif, yaitu serat-serat yang terutama direkrut selama olahraga aerobik. Perubahan-perubahan tersebut memungkinkan otot-otot tersebut menggunakan $\mathrm{O}_{2}$ secara lebih efisien. Sebagai contoh, mitokondria, dalam jalur fosforilasi oksidatif, meningkat jumlahnya di serat-serat oksidatif. Selain itu, jumlah kapiler yang memperdarahi serat-serat itu meningkat. Otot-otot yang telah beradaptasi demikian lebih mampu bertahan melakukan aktifitas berkepanjangan tanpa mengalami kelelahan, tetapi ukuran mereka tidak berubah.

Perubahan mencolok terdapat pada sistem kardiovascular saat berolahraga, termasuk peningkatan besar aliran darah otot rangka, peningkatan bermakna curah jantung, penurunan resistensi perifer total (karena vasodilatasi luas di otot-otot rangka walaupun terjadi vasokonstriksi umum disebagian organ besar lain, dan peningkatan sedang tekanan arteri ratarata . Bukti-bukti yang mengisyaratkan bahwa pusat-pusat olahraga, yang masih perlu diidentifikasi lebih lanjut, menginduksi perubahan jantung dan pembuluh darah pada permulaan olahraga atau bahkan dalam antisipasi olahraga. Efek-efek ini kemudian diperkuat oleh masuknya aferen ke pusat kardiofaskuler medula dari kemoreseptor di otot serta oleh mekanisme lokal yang mempertahankan vasodilatasi di otot-otot yang aktif. Refleks baroreseptor kemudian juga memodulasi respon-respon kardiovaskular ini. ${ }^{21}$

\section{KESIMPULAN DAN SARAN}

Dari hasil penelitian yang telah dilakukan, dapat diambil beberapa kesimpulan sebagai berikut: Terdapat perbedaan yang bermakna pada latihan dua kali dalam seminggu selama tujuh minggu terhadap $\mathrm{Vo}_{2}$ maks sebelum dan sesudah latihan. Terdapat perbedaan yang bermakna pada latihan empat kali dalam seminggu selama tujuh minggu terhadap $\mathrm{Vo}_{2}$ maks sebelum dan sesudah latihan. Terdapat perbedaan yang bermakna antara latihan dua dan empat kali seminggu 
selama tujuh minggu terhadap $\mathrm{Vo}_{2}$ maks. Latihan fisik akan meningkatkan kebugaran jasmani dengan indikator $\mathrm{Vo}_{2}$ maks.

Saran yang peneliti masukan untuk kedepannya sebagai berikut: disarankan melakukan olahraga aerobik rutin karena dapat meningkatkan kebugaran terutama daya tahan kardiorespirasi. Mencari tempat latihan yang tidak terganggu oleh faktor cuaca. Perlu dilakukan pengukuran $\mathrm{Vo}_{2}$ maks menggunakan metode Uji ergometer sepeda agar lebih akurat. Perlu dilakukan penelitian lebih lanjut dengan waktu latihan yang lebih lama. Menjalin hubungan yang kooperatif antara peneliti dan subyek penelitian

\section{REFERENSI}

O'Connor FG, Sallis RE, Wilder RP, Pierre PSt. Sport Medicine Just the Fact. International ed. Singapore: McGraw-Hill, 2005.

Guyton AC, Hall JE. Buku Ajar Fisiologi Kedokteran. Edisi 11. Jakarta: EGC, 2007.

Mahler DA. Pandual Uji Latihan Jasmani dan Persepsinya. Edisi 5. American Collage of Sport Medicine: EGC, 2003

Wilmore JH, Costill DL. Physiology of Sport and Exercise. 3rd ed. Champaign. Human Kinetics, 2005

Clarke DH. Exercise Physiology. University of Maryland: Prentice-Hall, 1975

Six Fundamentals of Fitness Training [Internet]. England: SkinnyBulkUp.com; 2010 [cited 2010 Jun 15]. Available from http://skinnybulkup.com/six-fundamentals-of-fitness-training/

VO2max [Internet]. Switzerland : BrianMac Sport Coach; 2011 [cited 2010 Jun 15]. Available from http://www.brianmac.co.uk/vo2max.htm

Hatfield, F.C. Fitness The Complete 'Guide. $7^{\text {th }}$ ed. Santa Barbara: International Sports Sciences Association, 2001 